\title{
National features for alternative motor fuels market
}

\author{
Anatoliy G. Goncharuk*
}

Department of Business Administration and Corporate Security, International Humanitarian University, 33, Fontanskaya Doroga Str., 420 Odessa, 65009, Ukraine

Email: agg@ua.fm

*Corresponding author

\section{Valerii I. Havrysh}

Department of Tractors and Agricultural Machinery, Operation and Maintenance,

Mykolayiv National Agrarian University,

9, Georgiy Gongadze Str.,

Mykolayiv, 54020, Ukraine

Email: havryshvi@mnau.edu.ua

\section{Vitalii S. Nitsenko}

Department of Accounting, Analysis and Audit, Odessa I.I. Mechnikov National University, 24/26, French Blvd., Odessa, 65058, Ukraine Email: vitaliinitsenko@gmail.com

\begin{abstract}
The objective of this study is the identification of specific national aspects that influence the alternative motor fuel usage. Empirical and statistical data have been used. For economical estimation of fuels, mathematical and economic modelling was used. World progress of society and the use of power resources trends have been shown. It is determined, that the last years' bioethanol production growth is almost stable. But biodiesel production has been slowing down. Efficiency of biofuels utilisation has been analysed. Biofuels production is most developed in countries which have favourable climate conditions, high developed agriculture, enough agricultural area and government support. General and specific barriers for biofuel usage have been examined. Regions of concentrated alternative fuels use have been revealed. Modern economic factors which influence on a production and applications of alternative fuels have been shown. Basic national features have been revealed.
\end{abstract}

Keywords: alternative motor fuels; biofuel; compressed natural gas; liquefied petroleum gas; consumption; production; feedstock; incentives; efficiency; country.

Reference to this paper should be made as follows: Goncharuk, A.G., Havrysh, V.I. and Nitsenko, V.S. (2018) 'National features for alternative motor fuels market', Int. J. Energy Technology and Policy, Vol. 14, Nos. 2/3, pp.226-249. 
Biographical notes: Anatoliy G. Goncharuk is a Full Professor, a Doctor of Economic Science (Dr. Habil), and has a PhD in Business Economics and Management. His research interests are in performance measurement and management, efficiency analysis, benchmarking and other methods and their application at various management levels in energetics, food and beverages, education and healthcare. He has written 11 monographs, 20 textbooks and has published over 160 articles in refereed national and international journals.

Valerii I. Havrysh graduated from Nikolaev Shipbuilding Institute with honours in 1988. Currently, he is the Head of the Department of Tractors and Agricultural Machinery. He has published 190 papers, including two textbooks and five monographs. He has developed the massive open online course alternative fuel management (http://www.iversity.org, Berlin, Germany). His field of research are alternative fuels and energy saving technology.

Vitalii S. Nitsenko graduated from the Odessa State Agrarian University in 2003. He is currently a Professor in the Department of Accounting, Analysis and Audit of the Odessa I.I. Mechnikov National University. He has published more than 200 scientific and educational works, including two sole monographs. His research interests are integration processes in the agro-food sector, food security, management of alternative fuels and energy saving technologies.

\section{Introduction}

In modern terms world community met with a serious problem - power safety. Its actuality is conditioned by growth of the role of environment on the efficiency of functioning of national economies at intensifying of competition on the markets of resources and products.

The ecological problems caused by application of fossil hydrocarbon fuels are intensified. Therefore, the application of alternative motor fuels, including renewable, assists strengthening of energy safety of every state, promotes the competitiveness of national commodity producers and improves an ecological situation.

The countries of the world are different from each other in terms of reserves of fossil energy resources, climatic conditions, legislation, the level of development of economy and science. All of these have an impact on the types and amounts of alternative fuels. Therefore, the aim of this research is to identify specific national aspects that influence the use of alternative motor fuels.

\section{Research methodology}

In this study, empirical data have been used. The authors have compared different sources of data, paying particular attention to the most frequently cited ones. In the study of the effectiveness of different types of fuels used economic and mathematical modelling. 
In the research indicators of provision, efficiency of production and utilisation have been used. We considered such indicators as energy cost; criterion of energy crop growing efficiency; ratio of fuel prices.

To make a decision on the use of a particular type of fuel is necessary to have information not only on their physical and chemical properties, and economic characteristics. To estimate economical attractiveness of the motor fuels the information about their prices are not sufficient. A consumer must know energy cost. The estimation of the effectiveness of different kinds of fuels subject to the effective values of equality engine efficiency. It is determined as follows.

$$
C E=\frac{F p r}{Q \cdot \rho}, \mathrm{USD} / \mathrm{GJ},
$$

where $F p r$ - the price of fuel, $\mathrm{USD} / \mathrm{m}^{3} ; Q$ - lower heat value of the fuel, $\mathrm{MJ} / \mathrm{kg}$; $\rho$ - density of the fuel, $\mathrm{t} / \mathrm{m}^{3}$.

In the case of the mixed fuels energy cost is determined as follows.

$$
C E=\frac{\sum_{i=1}^{n}\left(F p r_{i} \cdot g_{i}\right)}{\sum_{i=1}^{n}\left(Q_{i} \cdot \rho_{i} \cdot g_{i}\right)}, \mathrm{USD} / \mathrm{GJ},
$$

where $F p r_{i}$ - the price of the $i^{\text {th }}$ component of the fuel, $\mathrm{USD} / \mathrm{m}^{3} ; Q_{i}$ - lower heat value of the $i^{\text {th }}$ component of the fuel, MJ $/ \mathrm{kg} ; \rho_{i}-$ the density of the $i^{\text {th }}$ component of the fuel, $\mathrm{t} / \mathrm{m}^{3}$; $n$ - number of components; $g_{i}$ - share of the $i^{\text {th }}$ component of the fuel.

The efficiency of the internal combustion engine depends on a number of factors, including the type of fuel used. Thus, the efficiency of the diesel engine D-245.12S at maximum torque when running on diesel fuel is $37.5 \%$, and a mixture consisting of $40 \%$ rapeseed oil and $60 \%$ diesel fuel $-37.2 \%$.

Studies for spark-ignition brand ZMZ 405.2 have shown the following. The highest effective efficiency is observed when the engine operates on gasoline and propane $33.7 \%$. When the engine is running on methane the efficiency drops to $31 \%$. The maximum efficiency on biogas does not exceed $29 \%$.

Therefore, it is advisable to determine the energy cost that will be used for useful work

$$
C E E=\frac{C E}{\eta}=\frac{\sum_{i=1}^{n}\left(F p r_{i} \cdot g_{i}\right)}{\eta \cdot \sum_{i=1}^{n}\left(Q_{i} \cdot \rho_{i} \cdot g_{i}\right)}, \mathrm{USD} / \mathrm{GJ},
$$

where $\eta$ - the efficient of the engine.

Some biofuels are produced from crops. So, it is important to have information about profitability of the above production. The production of biofuels will be economically feasible if their energy cost is less than a similar indicator for a petroleum fuel, which cost is equal to the cost of harvest. If the excise tax for alternative fuel is equal to zero, a mathematical expression of the above conditions is as follows (Havrysh, 2007): 


$$
K=\frac{V_{b}}{V_{o}} \cdot \frac{Q_{b}}{Q_{o}} \cdot \frac{\rho_{b}}{\rho_{o}}
$$

where $Q_{b}, Q_{o}$ - lower heat value of biofuels and petroleum fuel, $\mathrm{MJ} / \mathrm{kg} ; \rho_{b}, \rho_{\mathrm{o}}-$ density, respectively, of biofuels and petroleum fuel, $\mathrm{t} / \mathrm{m}^{3} ; V_{b}-$ volume of biofuel, $\mathrm{m}^{3}$; $V_{o}$ - volume of petroleum fuel, $\mathrm{m}^{3}$.

It is necessary to take into account the selling of the by-products. For biodiesel these are cake and glycerine, for ethanol - carbon dioxide and dry fodder. The sale of these products allows to obtain additional funding for the purchase of petroleum fuel. This can improve the value of the criterion of biofuels production expediency.

In this case the equivalent volume of biofuels will be determined as follows

$$
V_{b}=\varphi \cdot U+U \cdot \frac{\sum_{i=1}^{n}\left(m_{i} \cdot C p r_{i}\right)}{F p r} \cdot \frac{Q_{o} \cdot \rho_{o}}{Q_{b} \cdot \rho_{b}},
$$

where $n$ - the number of co-products; $m_{i}$ - dimensionless output of the $i^{\text {th }}$ by-product; $C p r_{i}$ - the market price of the $i^{\text {th }}$ co-product, USD/t; $U$ - yield of energy crop, t/ha.

Then, the expression for the criterion is

$$
K=\varphi \cdot \frac{F p r \cdot Q_{b} \cdot \rho_{b}}{C p r \cdot Q_{o} \cdot \rho_{o}}+\frac{\sum_{i=1}^{n}\left(m_{i} \cdot C p r_{i}\right)}{C p r} .
$$

Thus, the economic feasibility of the biofuels production mainly depends on the ratio of the petroleum fuel and energy crop prices. Therefore, the price of energy plants (taking into account the co-products) must not exceed (Havrysh, 2007)

$$
C p r<\varphi \cdot \frac{F p r \cdot Q_{b} \cdot \rho_{b}}{Q_{o} \cdot \rho_{o}}+\sum_{i=1}^{n}\left(m_{i} \cdot C p r_{i}\right)
$$

Actually the criterion $K$ is a ratio of conventional/alternative fuel energy costs. If the excise tax for alternative fuel is not equal to zero, the formula for the above criterion will be

$$
K_{e t}=\frac{K}{\left(1+\varphi \cdot \frac{E T}{C p r}\right)}
$$

where $E T$ - excise tax for the alternative fuel.

Economical expediency of biofuel utilisation depends on the ratio between biofuel and conventional fuel prices. The ratio of conventional / alternative fuel energy costs

$$
R C A=\frac{C E_{C}}{C E_{A}}=\frac{\rho_{A} \cdot Q_{A} \cdot F p r_{C}}{\rho_{C} \cdot Q_{C} \cdot F p r_{A}} .
$$


In the above formula index ' $C$ ' means conventional fuel and index ' $A$ ' means alternative fuel. If ratio RCA is more than 1 , that the alternative fuel is preferable. From the formula (8), we can find optimal ratio of alternative/conventional fuel prices

$$
R C A P=\frac{F p r_{A}}{F p r_{C}} \leq \frac{\rho_{A} \cdot Q_{A}}{\rho_{C} \cdot Q_{C}} .
$$

\section{Energy resources and social formations}

The transition from one level of civilisation's maturity to another occurs due to the deep qualitative changes in the productive forces of society. These changes demand increasing the use of energy resources. American futurist E. Toffler called future coup 'third wave'. According to him, 10,000 years ago the first wave gave birth to the agrarian civilisation, and the second one was the source of an industrial society (Toffler, 1999). The third wave brings a new way of life, including the various renewable energy sources.

Another American scientist George Bell noted that the post-industrial society is a new principle of social and technological organisation and a new lifestyle, which displaces the industrial system. The characteristic features of post-industrial society should also include the greening of technological progress, dissemination of innovative waste technologies and renewable energy resources, which make it possible first to reduce the growth rate of consumption of natural resources, and then to reduce them as much as possible (Bell, 1999). Thus, the development of society is linked to the sources of energy.

Today, biomass is the fourth largest fuel in the world and annually produces about 2 billion tons of coal equivalents. This is equal to $14 \%$ of total world energy consumption. Biomass is a significant share of the energy consumption of economically developed countries such as the USA, Canada, Denmark, Austria, Sweden, Germany and some other (Borodina and Shevchyshyn, 2008).

If we analyse the share of renewable energy in the total energy balance of the various countries of the world, we can distinguish the following patterns. First, the largest share of renewable energy in the national energy balance has counties with low population density (Iceland $-70.7 \%$, Norway $-40.1 \%$; New Zealand $-29.7 \%$; Canada $-15.7 \%$ ) (Klavdienko and Tarasov, 2006). Second, in these countries the dominant role plays the energy of water, wind, geothermal and so on. Third, wood, wood waste processing and plants are dominated among biological raw material. It is also used to produce motor biofuels.

\section{Motor fuels}

Consumers can use both conventional and alternative motor fuels. The conventional fuels are fuels derived from petroleum. The alternative fuels are not petroleum fuels. Their use can improve both environmental and economic indicators of economic activity.

The first group includes petroleum products such as gasoline and diesel fuel (Figure 1). Alternative energy sources are divided into renewable and non-renewable. 
Figure 1 Classification of motor fuels

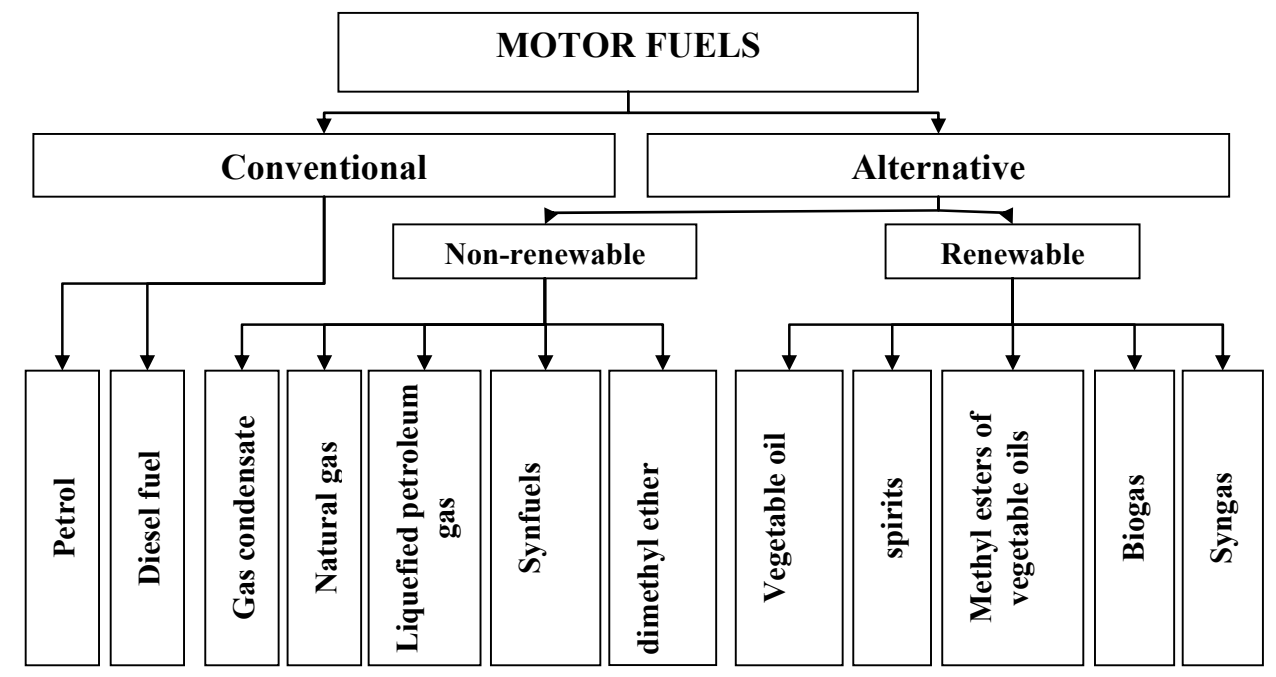

As a renewable resource for the production of motor fuels can be used fats, biomass, agricultural, industrial and household waste and others. Non-renewable fuels include natural gas, liquefied petroleum gas (LPG), gas condensate, synthetic fuels derived from coal and oil shale, dimethyl ether manufactured from natural gas.

Renewable fuels are made of raw materials of organic origin. They include vegetable oils, methyl esters of vegetable oils, alcohol fuels (bioethanol, methanol, buthanol, and oxygen-containing additives), biogas, syngas.

It should be noted that the main physics and chemical properties of biofuels differ from conventional petroleum properties. The above complicates their use. Therefore, in the heat combustion engines can be used mixed fuels containing petroleum and non-petroleum components. Their properties are similar to conventional fuels. The following combinations are used more widely: diesel fuel and vegetable oils; diesel fuel and vegetable oil methyl esters; gasoline and bioethanol.

The popular alternative fuels are biofuels. They are used widely in the world.

\section{Liquid biofuels production}

In 2014, the total world biofuels production amounted 70.79 million tones oil equivalent. The world leaders are (million tones oil equivalent): USA - 30.056; Brazil - 16.656; Germany - 2.684; Argentina - 2.577; Indonesia - 2.444. The USA and Brazil produce $66 \%$ the total world production.

The widespread biofuels are ethanol and biodiesel. The total world ethanol production exceeded 94 million $\mathrm{m}^{3}$ and biodiesel -31 (Figures 2 and 3). Share of ethanol (energy equivalent) among biofuels is equal to $66.76 \%$. 
Figure 2 Global fuel ethanol production (see online version for colours)

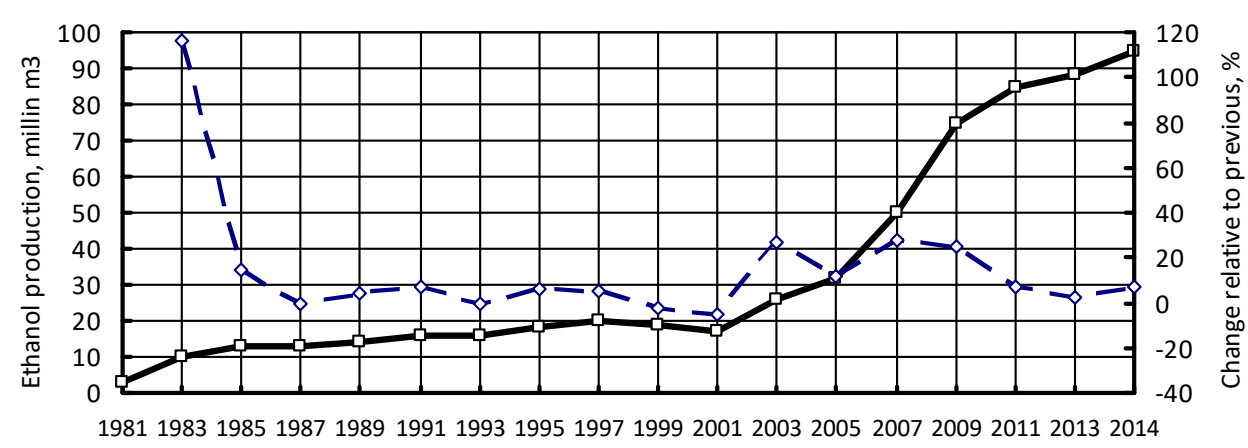

$\longrightarrow$ ethanol production $-\approx$ change relative to previous

Figure 3 Global biodiesel production (see online version for colours)

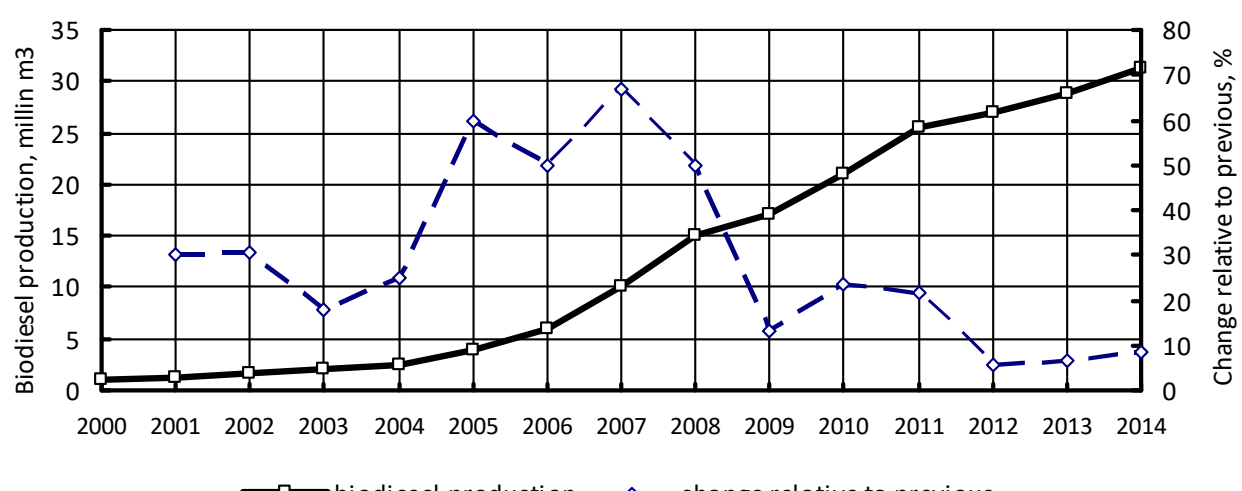

The change of bioethanol production relative to previous period is almost stable last 30 years (Figure 2). As to biodiesel, since 2007 the rate of its production has been becoming slower (Figure 3).

The top of biofuel producers is headed by the USA (Tables 1 and 2). Only the EU can compete with the US in terms of the production of biodiesel. In 2014, EU produced 12.661 million $\mathrm{m}^{3}$ of biodiesel and 5.25 million $\mathrm{m}^{3}$ of ethanol.

Table 1 Top fuel ethanol producers, 2014

\begin{tabular}{lcc}
\hline Country or region & Volume, million $\mathrm{m}^{3}$ & Primary feedstock \\
\hline USA & 54.126 & Corn \\
Brazil & 26.328 & Sugarcane \\
China & 2.403 & Corn \\
Canada & 1.800 & Corn $/$ wheat \\
France & 1.18 & Wheat $/$ sugar beet \\
Total & 94.639 & \\
\hline
\end{tabular}


Table 2 Top biodiesel producers, 2014

\begin{tabular}{lcc}
\hline Country or region & Volume, million $\mathrm{m}^{3}$ & Primary feedstock \\
\hline USA & 4.728 & Soy, corn oil, canola, used cooking oil \\
Brazil & 3.401 & Soybeans \\
Germany & 3.390 & Rapeseed, used cooking oil \\
Indonesia & 3.107 & Palm \\
Argentina & 2.881 & Soybeans \\
Total & 31.337 & \\
\hline
\end{tabular}

The primary exporters of fuel ethanol are the USA and Brazil (Figure 4). Argentina and Indonesia exported approximately $10 \%$ of total world biodiesel production (Figure 5). Indonesia and Argentina produce biodiesel primarily to export. They use the market situation to get profit from biofuel demand (Figure 6).

Figure 4 USA and Brazil fuel ethanol net export

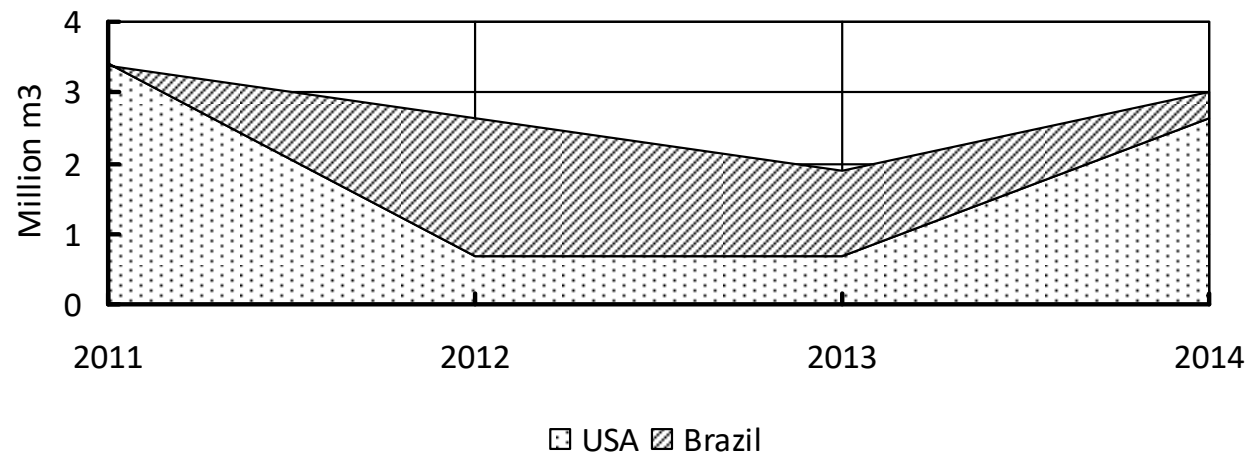

Figure 5 Argentina and Indonesia biodiesel net export

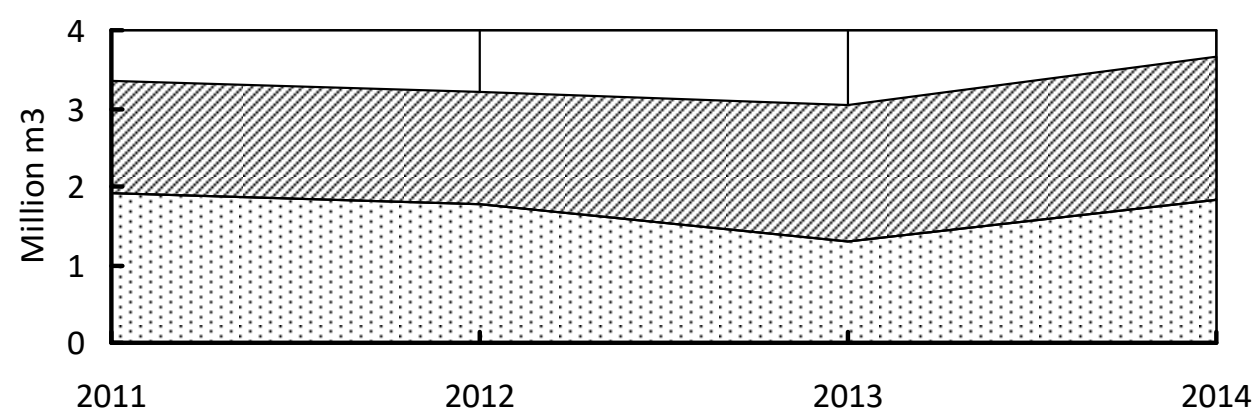

Argentina $\square$ Indonesia 
Figure 6 The share of exports/imports in domestic consumption of biofuels (see online version for colours)

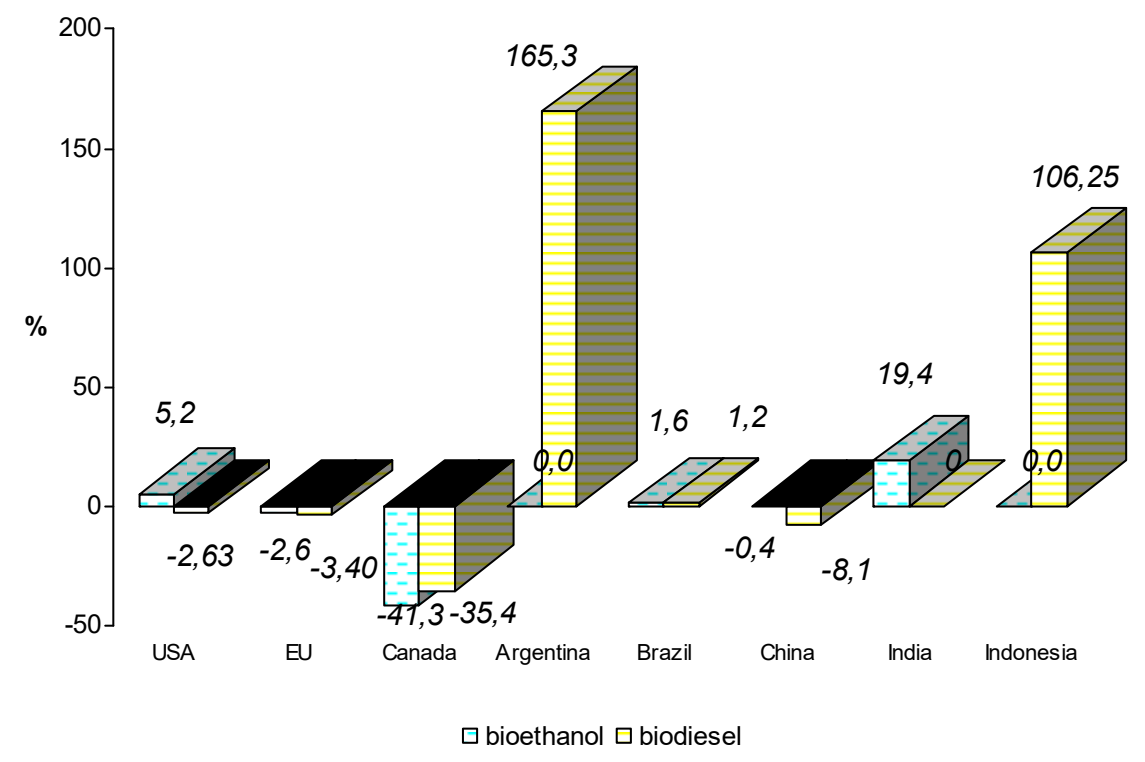

Countries face impediments for the development of biofuels.

\section{Barriers for biofuel usage}

The importance of identifying barriers that are hindering the realisation of the potentials of an advanced biofuels industry in the world, so to contribute to removing them through targeted recommendations and strategic advice.

There are general and specific for each country barriers. The general barriers are economic (one of the principal barriers for the use of biofuel in general is the competition with fossil fuel on a direct production cost basis); infrastructure (insufficient availability refuelling infrastructure); vehicles adopted for biofuels (limited number of flex-fuel cars are also barriers for widespread ethanol use) (Wisner, 2012); and technology.

The following problems are characterised for China: administrative and legal barriers (the lack of a long-term federal-provincial planning for both first and second generation biofuel); information and acceptance barriers (impact of biofuels production on the food security and agriculture development; potential ecological environmental problems caused by large-scale cultivation of energy crops) (Shiyan et al., 2012).

Brazilian scientists have identified two further issues: ecological and social. Large-scale biomass production may pose various ecological and environmental issues that cannot be ignored. It is possible loss of biodiversity, soil erosion, fresh water use, nutrient leaching and pollution from chemicals. The large scale energy plantations have the social implications. It impacts on employment (which may increase, or decrease, depending on the level of mechanisation, local conditions, etc.), potential use of child labour, education and access to healthcare (Moreira, 2007). 
Ukraine has not large scale biofuel production despite the favourable climate and land area. The main barriers to increasing biofuels use are legislative and financial. There are no standards and certification system. Unstable political and economic situation has a negative impact on the development of market relations. It should also be noted (Yerokhin, 2009):

- lack of trained specialists (preparation and implementation of projects, technical service units)

- insufficient level of awareness of all stakeholders (farmers, investment companies, businessmen and population)

- conflict of interest with the conventional motor fuel supply companies.

\section{Efficiency of biofuels utilisation}

The world practice shows, the using of the alternative fuels is attractive either because of lower cost or because of economic incentives. Examples of the first direction are compressed natural gas $(\mathrm{CNG})$ and second direction - biofuels in EU, USA, etc.

The ratio between alternative and conventional fuels prices must be below than values presented in Table 3.

Table 3 The price ratio of some alternative fuels

\begin{tabular}{lcc}
\hline \multirow{2}{*}{ Alternative fuel } & \multicolumn{3}{c}{ Conventional fuel } \\
\cline { 2 - 3 } & Gasoline & Diesel fuel \\
\hline Biodiesel & - & 0.907 \\
Rape oil & - & 0.937 \\
CNG & 1.061 & 0.919 \\
LPG & 0.776 & 0.672 \\
Ethanol & 0.695 & - \\
\hline
\end{tabular}

Note: *The calculated figures may be variable depending on physical properties of fuels.

The cheapest bioethanol is produced in Brazil (Fay and Barros, 2013). Despite it the national average ratio is some more than optimal value. Gasoline prices still remained competitive in several Brazilian states (Barros, 2014). This results that since 2009 consumption of ethanol as a motor fuel has been coming down: from 16.470 million $\mathrm{m}^{3}$ to $10.816 \mathrm{mln} \mathrm{m}^{3}$ in 2013 (Agência Nacional do Petróleo, Gás Natural e Biocombustíveis, 2014).

However, in the most cases, the production cost of biofuels and synthetic fuels are higher than the production cost of conventional fuels. That is why it is necessary to use of economic incentives:

- reduction of the excise tax

- the tax credit

- compensation of the investment costs in alternative fuel plants 
- quota consumption of biofuels

- $\quad$ environmental payments

- $\quad$ subsidies to producers of bioenergy raw materials.

Their use helps to increase of the biofuels consumption. For example, in Germany, biodiesel consumption reached record levels in 2007 (Figure 7). First of all, to bring biofuels to the market it is necessary to apply a reduced excise tax, and further they use quotas and support for producers of bioenergy raw materials (EBB, 2011; Federal Government of Germany, 2006, 2007, 2011; VDB, 2011a, 2011b, 2011c). As can be seen, the reduction of financial support results some decline in the production of biodiesel.

Figure 7 Dynamics of biofuels consumption in Germany

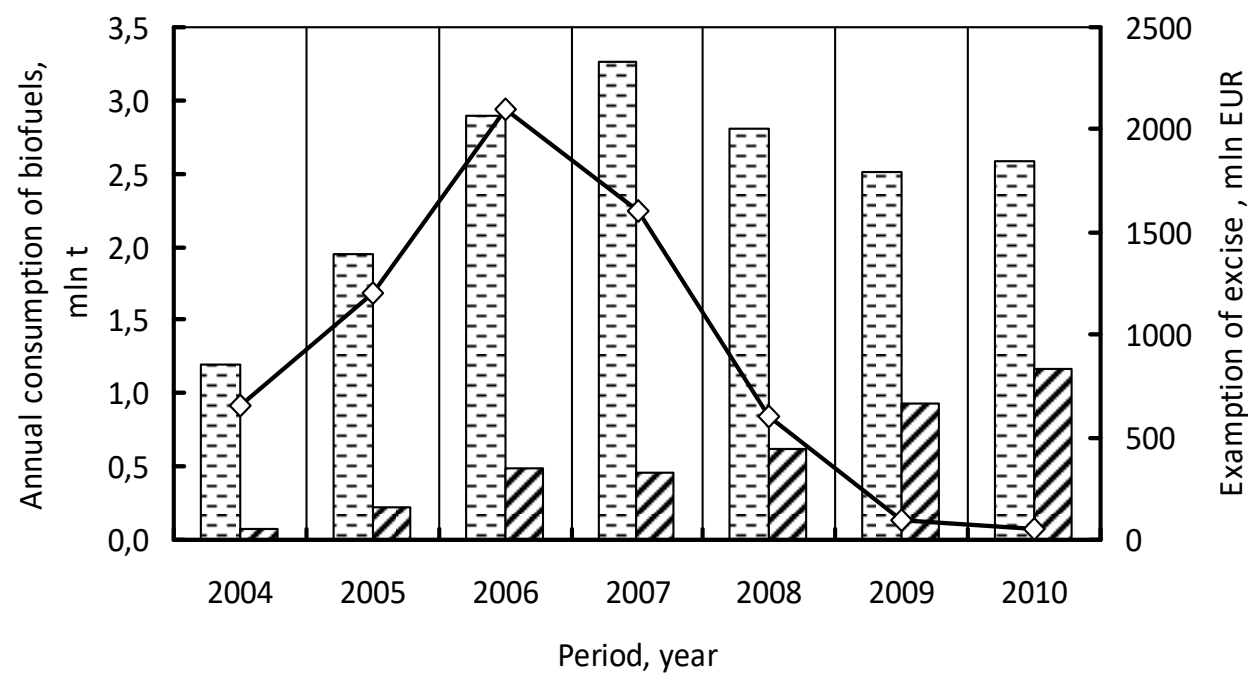

E--- Biodiesel consumption $\mathbb{Z Z}$ Bioethanol consumption $\prec$ examption of excise tax

There are countries with low and high value of excises. For example, the first group includes the USA. In this country at the beginning of 2015 excise taxes on motor fuels were equal to, USD/gallon (EUR/1,000 litres): gasoline - 0.2412 (59.29); diesel fuel 0.249 (61.21); gasohol - 0.2408 (59.19) (Federation on Tax Administrators, 2015). The low value of these taxes reduces the border for price formation. As a result the CNG is the most economically attractive motor fuel (Figure 8) (US Department of Energy: Energy Efficiency and Renewable Energy, 2014). Moreover, CNG is economically attractive, even with a sharp drop in crude oil price (Figure 9). 
Figure 8 The energy cost in the USA

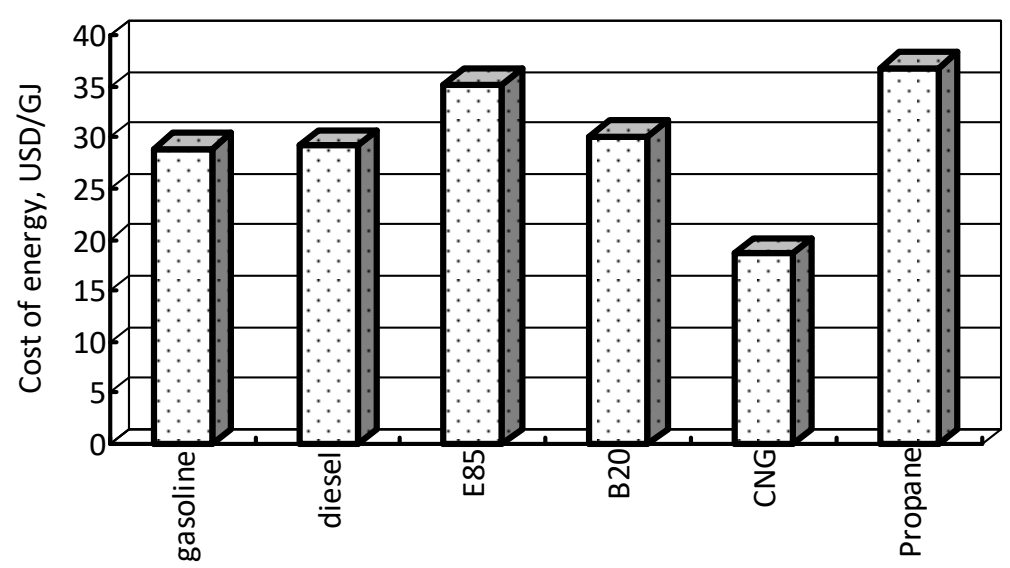

Figure 9 Dynamics of motor fuels prices in the USA

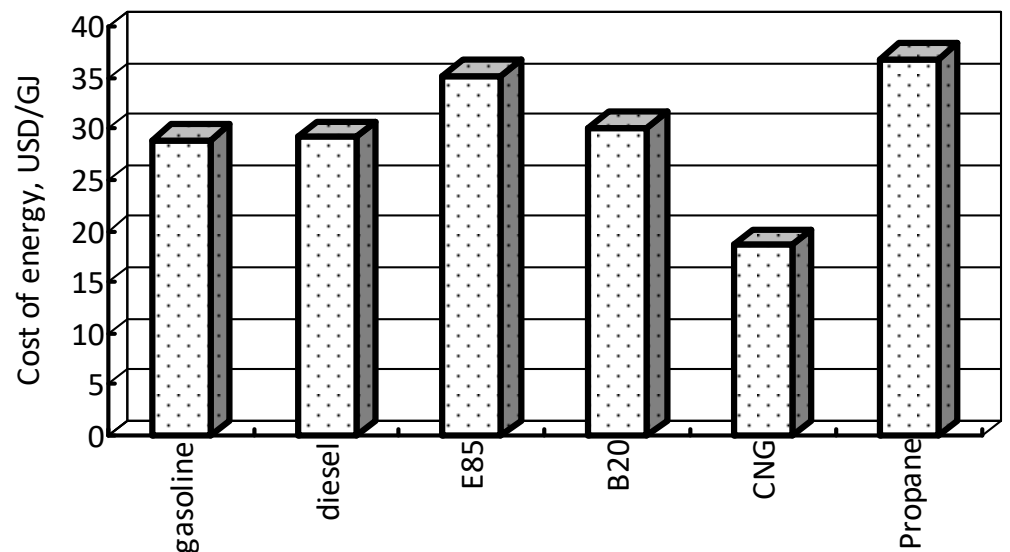

Figure 10 The ratio alternative/conventional fuel prices (actual ratio of prices) (see online version for colours)

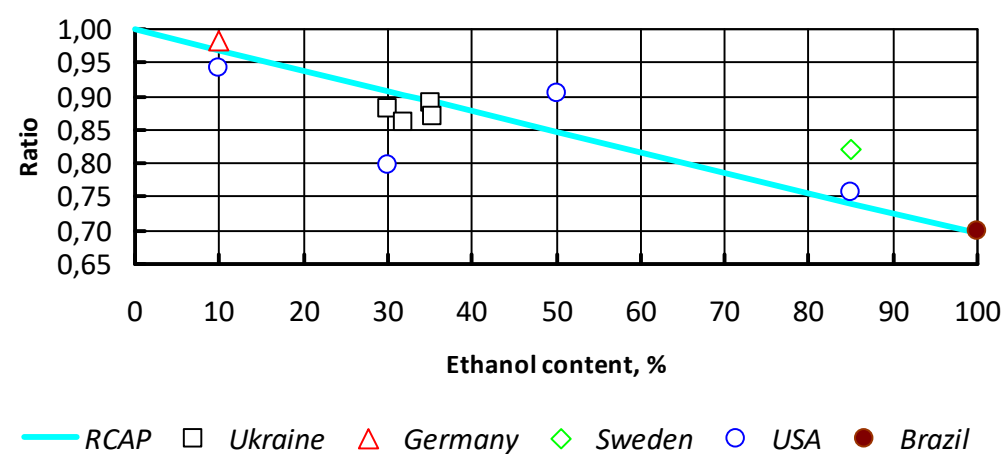


As to ethanol using, its efficiency depends on a lot of factors. For example, energy cost of E85 in the USA and Sweden, E50 in the USA and E10 in Germany are higher than the energy cost of gasoline. But E10 and E30 in the USA and E95-40 in Ukraine the blended fuels (share of ethanol less $40 \%$ ) are competitive (Figure 10).

In some countries, such as the EU, high excise taxes on the motor fuels are applied. Their values are from EUR359 per 1,000 litres to EUR750 per 1,000 litres for gasoline and from EUR330 per 1,000 litres to EUR660 per 1,000 litres for diesel fuel (propellant) (European Commission, 2016). This allows to form an economically attractive price for the alternative fuels by regulating the rates of excise taxes.

A number of countries have large reserves of the crude oil and pursue a policy of low prices for motor fuels inside the country (Figure 11) (The Statistics Portal, 2014). Naturally, it does not stimulate the development of alternative energy sources.

Figure 11 The price of gasoline in some countries (October 2014)

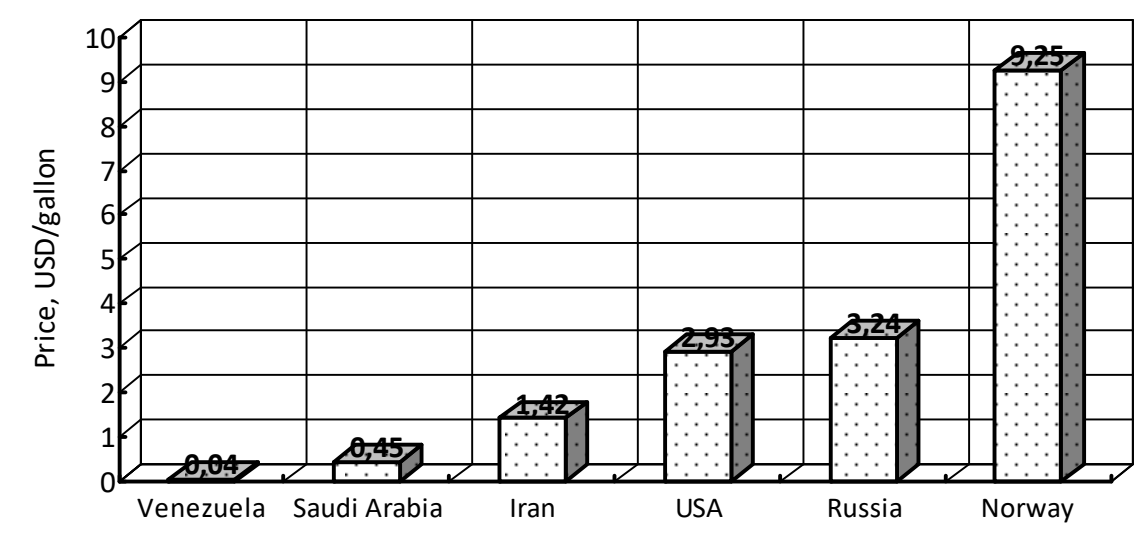

The production and use of alternative fuels, including biofuels, should be economically feasible. As a rule, in EU countries a production cost of biofuels is higher than petroleum fuels. For example, as of 2010, the production cost in Germany was equal to, EUR/liter: diesel fuel -0.45 ; gasoline -0.42 ; biodiesel -0.84 ; bioethanol -0.58 . Today, tax exemptions for biofuels are not provided. Exceptions are biofuels of second generation (cellulosic ethanol), biogas and bioethanol as E85, which are exempt from excise tax. Pure biodiesel (B100) and vegetable oils as fuel to 2012 were subjected to preferential taxation. The use of expensive biofuels is stimulated by a quota system (Rauch, 2012).

The introduction of alternative fuel motor in agricultural production may be constrained by the available programs to support producers. For example, in EU countries the preferential prices for diesel fuel limit application of the ecologically clean fuels.

Biofuels are mainly produced from crops.

\section{The feasibility of energy crop growing}

Biofuels production is most developed in countries with favourable climatic conditions, agricultural efficiency and availability of appropriate government support. Thus, the 
average yield of bioenergy raw materials for the production of bioethanol is, $t /$ ha: sugar cane (Brazil) - 77; corn (USA) - 10.8; maize (EU) - 6.94; Sugar beet - 67.85 (Crop Monitoring in Europe, 2012; MECAS, 2012). This allows to produce the following volumes of bioethanol from one hectare, 1/ha: Brazil - 5,621; USA - 4,320; EU (corn) 2,776; EU (sugar beet) - 7,463. In due to the low production cost of sugarcane, the bioethanol production is more economically attractive in Brazil. In the EU countries, despite the high bioethanol yield per unit area, due to the relatively high production cost of bioenergy raw materials, the bioethanol production is less competitive in comparison with Brazil.

The situation in the biodiesel production is somewhat different. The average yield of rapeseed in the EU is $3.0 \mathrm{t} / \mathrm{ha}$. The high rates have the following countries, $\mathrm{t} / \mathrm{ha}$ : Belgium - 4.11; Germany - 3.66; UK - 3.49; Denmark - 3.54 (Crop Monitoring in Europe, 2012). This creates the conditions for the effective production of biodiesel. That is why the EU is a world leader in the production and use of biodiesel. Although significant volumes of raw materials and the ready biodiesel are imported.

Let consider the determination of the expediency of the cultivation of crops for biofuel production. The production of biofuels generates co-products. For biodiesel these are (rapeseed, soybean, etc.) meal and glycerine.

The results of calculations for the production of biodiesel in Ukraine are shown in Figure 12. As can be seen, the production of this kind of fuel without economic incentives is inappropriate. There are only certain times when the production of biodiesel is economically justified. So, it is observed the second half of 2014.

Figure 12 Dynamics of the criterion $K$ for biodiesel in Ukraine

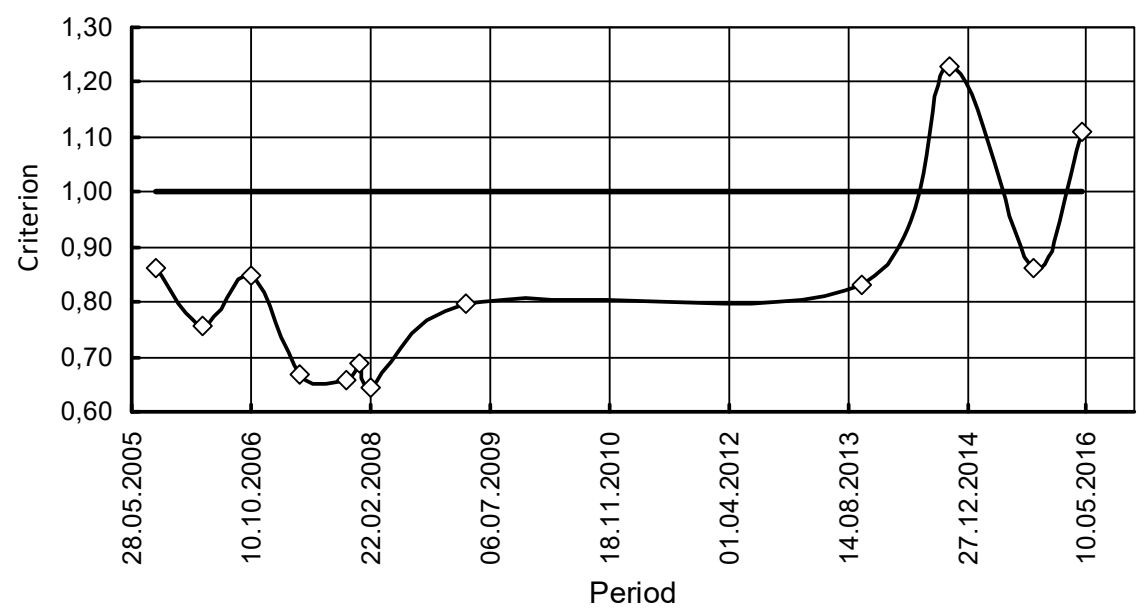

Last five years in Germany, the criterion $K$, calculated by the formula (4), was between 1.15 and 1.58 (biofuel excise tax is equal to zero) (Figure 13). The maximum acceptable biodiesel excise tax last two-year does not exceed an actual excise tax for diesel fuel. All biofuels - in blended or pure form - that are used to meet the quota are subject to standard excise taxes on fuel, except for second generation biofuels. Blended fuels are only supported via the quota system and are no longer subject to tax reliefs. 
Figure 13 Criterion $K$ and excise tax for biodiesel in Germany (see online version for colours)

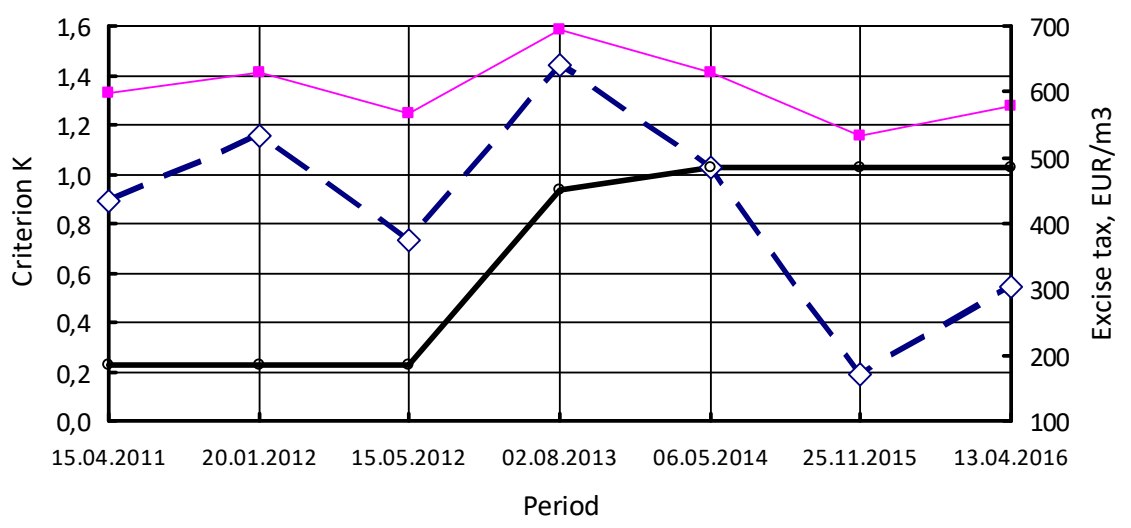

$\longrightarrow \mathrm{K} \longrightarrow-$ Maximum excie tax $\longrightarrow$ Actual excise tax

Regarding the production of bioethanol, the situation is somewhat different. The efficiency depends on the energy crops and using co-products. The ethanol dry-milling process generates $386 \mathrm{~kg}$ of Dry Distiller's Grain per Mt of corn processed into ethanol. It may be sold at a price of $\operatorname{USD}(120 \ldots 140) / \mathrm{t}$. Utilisation of the co-products can reduce production cost by $20 \%$. The ethanol production from sugar cane does not generate co-products. But bagasse can be used for electricity generation.

Process of ethanol fermentation generates carbon dioxide. The practice shows that $95.65 \mathrm{~kg}$ of carbon dioxide can be obtained per $100 \mathrm{~kg}$ of ethanol. This gas is a commodity and can be sold and give additional income.

The efficiency of ethanol producing depends on the climate conditions. If criterion $K$ of ethanol production from sugar cane in Brazil we assume as $100 \%$, that in different country it will be less: the USA - 34\%; Thailand - 62\%; India - 83\%; Australia - 85\%. That is why, for example, in the USA corn is used to produce ethanol.

In some countries affected by high prices for conventional fuel biofuel production is impossible due to climatic conditions. Not all countries have enough agricultural area to grow the raw material for substitution of conventional fuels. Such in according to I. Kirilenko, the necessary area of agricultural land to substitute $30 \%$ of conventional transportation fuels (diesel fuel and gasoline) amounts (in percent of total agricultural land): Ukraine - 9; USA - 100.8; Brazil - 40.5; French - 82.5; Germany - 131.3 (Kirilenko et al., 2009).

Researches of Adrian Zhou and Elspeth Thomson have shown that Indonesia, Malaysia, the Philippines, Thailand, (the) People's Republic of China and India are largest biofuels producers in Asia (Zhou and Thomson, 2009).

The biggest country of the world (China) develops its own biodiesel industry. It is estimated that China's new consumption of biodiesel during 2014-2017 will go beyond 2.5 million tons and ethanol -1 million $\mathrm{m}^{3}$ (Xu et al., 2016).

As to India, the biodiesel fuel is not commercialised now. As a raw material the prospect plant is jatropha. It is an attractive resource for biodiesel production in India as it can be grown on waste land and does not need intensive water supply. Ethanol will make up $2.1 \%$ of India's fuel supply (Leduc et al., 2009). 
As a result of national efforts the volume share of biofuel reached $10.1 \%$ for bioethanol and 3.5\% for biodiesel (Figure 14).

Figure 14 Volume share of biofuels, \% (see online version for colours)

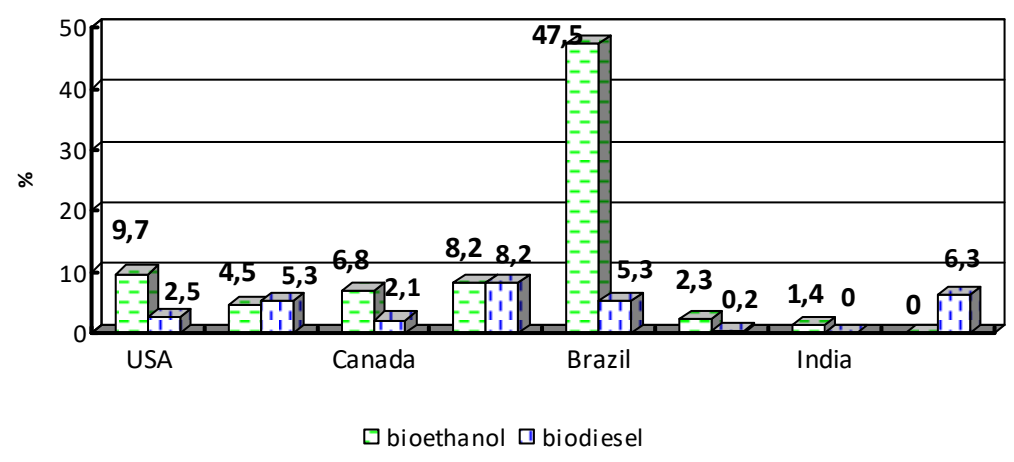

\section{Incentives for biofuels usage}

Support for biofuels can be provided at different levels - from the production of biomass to the consumption of blended (or unblended) fuel. Incentives may be grouped as following: market mandate; support for farmers (production of biomass); support for biofuel producers.

\subsection{Market mandate}

As a rule, biofuel policies rely on supporting the demand for biofuels, through subsidies and tax credits. The mandates serve to control the share of biofuel. Blending mandates or targets (mainly expressed as volumetric content) exist in 62 countries around the world (http:/www.biofuelsdigest.com/bdigest/2013/12/31/biofuels-mandates-around-the-world2014). For example, in the USA, the Renewable Fuel Standard (RFS) establishes minimum volumes of renewable fuels that must be included in the USA' supply of fuel for transportation by 2022 .

It requires the use of 36 billion gallons of renewable fuels (including 2 billion gallon of biodiesel, or 5.5\%). Under the RFS, renewable fuels would make up about $18 \%$ in 2022 (US Congress, 2014). The US mandate for the use of biofuels is more complex compared with similar documents of other countries but will undoubtedly continue to have a major role in the future of the biofuel sector.

In the case of Brazil, the mandates take the form of compulsory blending of ethanol into transport fuel. In September 2014, President Roussef sanctioned Bill \# 13.033/14, which increased the maximum ethanol blend in gasoline from $25 \%$ to $27.50 \%$. The current biodiesel blend remains at 7\% (Barros, 2015).

Asia countries increase biofuel blend (Anderson-Sprecher and Ji, 2015). China promulgated the medium- and long-term Development Plan for Renewable Energy in 2007, which included targets of 2010 and 2020 for biofuels. The 2010 biofuel targets were met. China plans to produce 10 million tonnes ethanol and 2 million tonnes biodiesel in 2020 (Shiyan et al., 2012). 
As to EU, that the 2009 EU Energy and Climate Change Package (CCP) includes a $10 \%$ minimum target for renewable energy consumed by the transport sector to be achieved in 2020. But on April 28, 2015, the European Parliament's (EP) scaled back the mandate to the $7 \%$.

Special situation is in Indonesia. In this country biodiesel mandate has been aggressive historically. In 2014, blending rates were set at 10\% for 2014 and 2015 . Indonesian Biodiesel Mandatory Targets contain both export and domestic consumption of biodiesel (Figure 15) (Wright and Rahmanulloh, 2015). The same situation is in Argentina.

Figure 15 Indonesian biodiesel mandatory targets (see online version for colours)

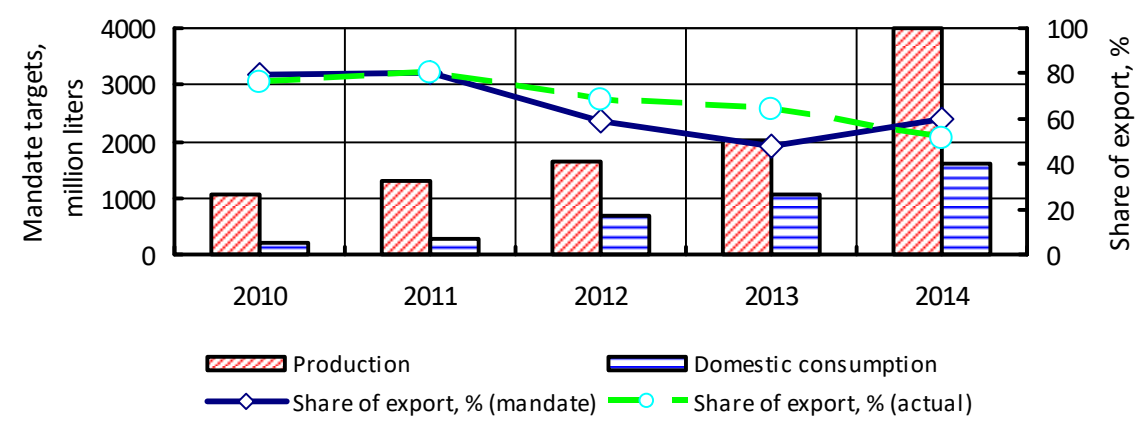

\subsection{Support for farmers}

The USA has a lot of farm programs that support the production of corn and soybeans. They operate regardless of the final use of the crop - for food or fuel (Josling et al., 2010).

Brazil has few programs presently that specifically subsidise the production of sugar cane (Nassar and Ures, 2009). These programs aim to offset the high cost of credit in Brazil. But as a result of the low production cost of sugar cane, the biofuel sector is therefore competitive without subsidising feedstocks.

Biofuels consumed in the EU in 2008 have been produced from feedstock growing on land area of approximately 3.6 million hectares. Producers of feedstock for biofuels within the European Union are supported indirectly through the Single Payment Scheme (SPS) of the EU Common Agricultural Policy (CAP). Under the SPS scheme, there is no direct support, but the areas cultivated for biofuel feedstocks are, like those for food crops, eligible for SPS payments. Germany had the highest SPS payments - EUR346/ha. Average EU SPS payments are equal to EUR266/ha (Charles et al., 2013).

\subsection{Incentives for producers}

The primary mechanism is a reduction in the excise tax on motor fuels. For example, in the USA federal gasoline excise tax rate of 18.4 cents per gallon is reduction of 5.2 cents per gallon for E10. The excise tax and income tax encourage the application of biofuels in the national market. This supports of the biofuel industry (Anderson-Sprecher and Ji, 2015). 
The biofuel production industry may be supported through loan, loan guarantee and grant programs too. Now, the US Department of Agriculture programs open to current and prospective ethanol producers were authorised by the Farm Security and Rural Investment Act of 2002 (or the 2002 Farm Bill) (MacDonald, 2004). The Agricultural Act of 2014 (or the 2014 Farm Bill) expands biofuels programs (Farm Security and Rural Investment Act of 2002, 2002).

In China, wholesale price of fuel ethanol is the ex-factory price of 93\# gasoline multiplied with the factor of 0.911 . Specific subsidies to offset production cost. For biodiesel, consumption tax is exempted (Shiyan et al., 2012).

\section{Encouraging the use of the gaseous motor fuels}

There are renewable (biogas) and non-renewable (CNG and LPG) gaseous fuels. To encourage the use of gaseous fuels such as natural gas and especially biomethane the reduced tax rates are applied. For example, in the Baltic States biomethane is taxed at a zero rate, and natural gas is taxed significantly lower than the fossil fuels (Figure 16) (Benjaminsson, 2012).

Figure 16 Tax rates on fuels in the Baltic States

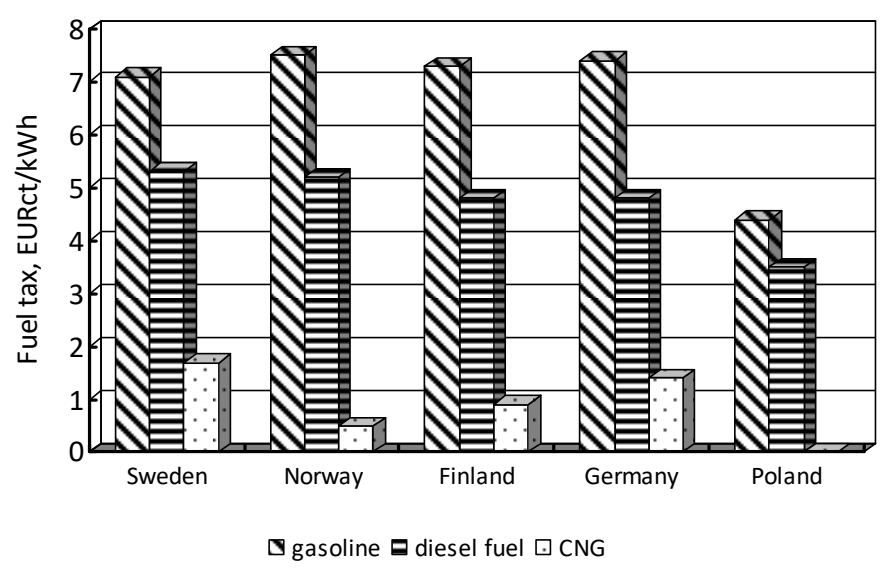

Now in the world, there are more than 22.4 million natural gas vehicle. The average natural gas consumption exceeds more than 2.18 billion $\mathrm{m}^{3}$. The biggest operators of NGV are, million: Iran - 4.1; China - 3.9; Pakistan - 3.7; Argentina - 2.5; India - 1.8; Brazil - 1.78 (NGVJournal). The main reason is the low energy cost of gaseous fuel. The leader in natural gas trucks fleet is Ukraine. It amounts more than 70,000 vehicles.

The biggest amount of NGV is concentrated in Asia $-57 \%$. The main reasons are the following:

- Middle East has $42.7 \%$ of total world natural gas proved reserves.

- Competitive price of gaseous fuel (Figures 17 and 18).

- Relatively high density of population or compact habitation. It decreases expenses on refuelling stations infrastructure. 
Vice versa, Russia has $17.4 \%$ of the total proved reserves. However, vast territory does not promote for development of the necessary infrastructure.

Figure 17 Ratio LPG/petrol fuel prices (see online version for colours)

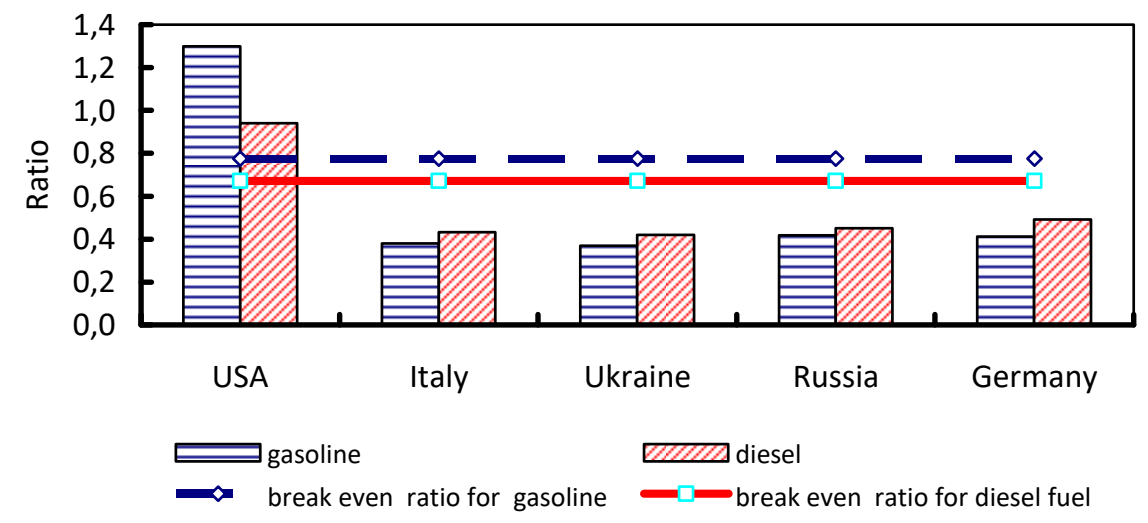

Figure 18 Ratio CNG/petrol fuel prices (see online version for colours)

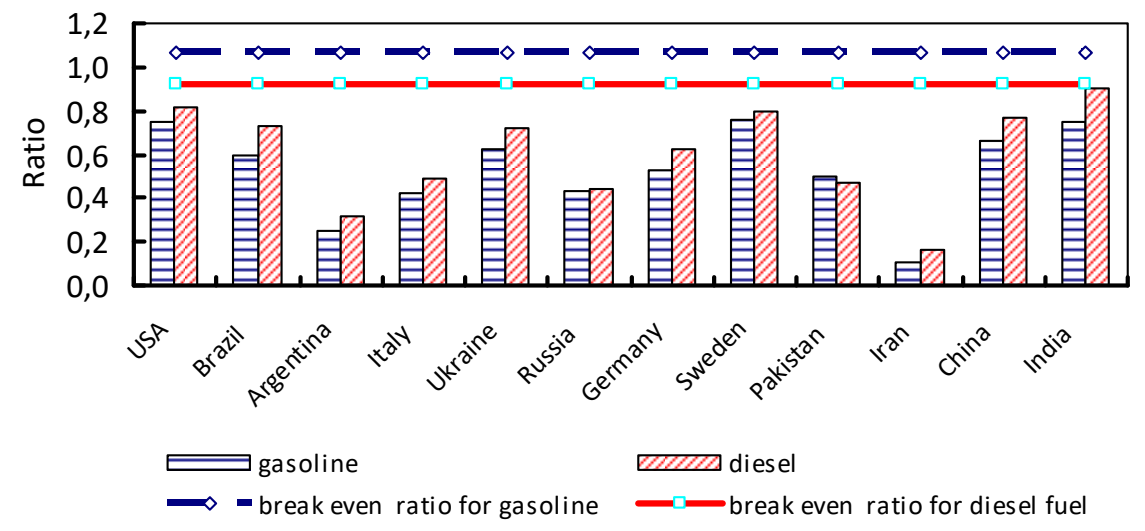

As can be seen, the gaseous fuels are competitive for the most countries. Argentina, Italy, Iran and Pakistan have the most favourable price situation.

There is an interesting experience in Sweden to encourage the use of alternative fuels. It covers all areas - from investment in fuels to environmental charges (Benjaminsson, 2012):

- investment grants in the production of the biofuels

- $\quad$ reducing income taxes

- lack of parking fees

- government award for eco-friendly cars

- reducing taxes on gas-cylinder cars. 
For example, the new environmentally friendly cars are exempt from taxes for five years. For comparison, the annual environmental payments for diesel cars are EUR460, and gasoline cars - EUR230.

The construction of new biogas and biomethane plants gets the investment grants from $20 \%$ to $30 \%$ of the total investment cost. As a result, the annual consumption of the biomethane and natural gas as a vehicle fuel exceeds 1.66 times.

On the contrary, in countries where there is not enough fossil energy resources, but there is a clear energy strategy, there is a build-up of production of alternative fuels. An example is China People Republic. Today, this country ranks first in the world in biogas production (15 billion $\mathrm{m}^{3}$ per year) $(\mathrm{Li}, 2014)$.

\section{Impact of biofuel production on food prices}

The development of biofuels has caused a debate about its impact on food prices. The analysis of links between biofuels, food price rises and food security is particularly difficult. A large number of economic studies have analysed relationships between biofuels production and food prices (Drabik, 2012; Mallory et al., 2012; Tokgoz et al., 2012; Vacha et al., 2012; Wright, 2011). Biofuels provoke a rise in food commodity prices, the controversy still persists on the extent of this impact, and their role in driving price volatility (Abbott, 2012).

The turning point of this discussion was the report of the European Commission, which states that if biofuels has not such significant political support, food prices would be $15 \%$ lower in the world than it is today. They also point out that the scale of growth will depend on the level of biofuel production and the share of biofuels so-called second generation. Advanced biofuels can be derived from non-food, energy crops or agricultural, forestry and municipal wastes.

The European Commission has proposed within the Renewable Energy Directive reduction in the use of first-generation biofuels (biofuels produced from food crops) in the transport sector from $10 \%$ to $5 \%$. September 11, 2013, the EP decided that first generation biofuels can be only $5.5 \%$ of the $10 \%$ share of biofuels in the transport sector. The rest should consist of second-generation bio-components. A recent manifestation was the formation of the 'Leaders of Sustainable Biofuels' dedicated to the rapid promotion of 'no-food competing feed-stocks' (Manifesto, 2013).

The production of second-generation biofuels can compete with other forms of bioenergy such as biogas. For instance, biogas also involves traditional process technology but is normally associated with waste or residues and so can be seen as non-competitive with food crops. It is a widely used form of energy in Asian countries. In the EU, for example, the UK relies almost entirely on landfill and sewage sludge gas.

\section{Conclusions}

1 The development of the alternative fuels market in the world is dictated by the reduction in conventional energy resources, and environmental degradation. These reasons led to stable growth in the production of the alternative fuels including the biofuels. 
2 Three regions of concentrated alternative fuel use may be distinguished:

- Natural gas $-57 \%$ of NGVs are operated in Asia.

- Biodiesel - The EU countries consume $40.4 \%$ of total world biodiesel production.

- Ethanol - The USA uses $57.2 \%$ of total world ethanol production.

3 The largest share of ethanol in gasoline is used in Brazil (47.5\%).

4 Argentina and Indonesia are exporting more than $50 \%$ of its own biodiesel produced.

5 The development of the alternative fuels market in the world is dictated by the reduction in conventional energy resources, and environmental degradation. These reasons led to stable growth in the production of the alternative fuels including the biofuels.

Provision of energy resources of any stat country can be carried out in two directions.

First, the economically developed countries (with relatively low self-sufficiency in primary energy resources) cover their deficit at the expense of imports. Sufficient financial resources allow stimulating the use of all kinds of the alternative motor fuels.

Second, developing countries, due to lack of finance resource, use a strategy of self-limitation of energy consumption. They are developing the using only those alternative fuels, which are cheaper than conventional ones. That is why in 2015, the Government of Ukraine announced plans to minimise financial support of alternative energy.

The economic incentives can be affordable for developed countries, but developing countries have no opportunity to use them.

6 Currently, the most widespread alternative motor fuel is CNG, as the cheapest fuel, and bioethanol, as the cheapest biofuel.

\section{References}

Abbott, P. (2012) 'Biofuels, binding constraints and agricultural commodity price volatility', Paper presented at the NBER Conference on 'Economics of Food Price Volatility', Seattle, USA, 16 August 2012.

Agência Nacional do Petróleo, Gás Natural e Biocombustíveis (2014) Boletim Anual de Preços 2014: preços do petroleo, gás natural e combustíveis nos mercados nacional e internacional, 180pp, ANP, Rio de Janeiro.

Agricultural Act of 2014 (2014) 3 January, 357pp, Washington.

Anderson-Sprecher, A. and Ji, J. (2015) China Biofuel Industry Faces Uncertain Future, GAIN Report No. CH15030, 14pp.

Barros, S. (2014) Biofuel Annual, 27pp, USDA Foreign Agricultural Service, Brazil.

Barros, S. (2015) Brazil Biofuel Annual Report 2015, Gain Report No. BR15006, 31pp, USDA Foreign Agriculture Service.

Bell, D. (1999) The Coming of Post-Industrial Society: Social Forecasting Experience, 246pp, Academia, Moscow. 
Benjaminsson, J. and Rojas, N. (2012) Instruments for Increased Use of Biogas in the Transport Sector: A Comparative Analysis of Measures for Introduction of Biogas as Fuel, 6 September, 51pp, Baltic Sea Region, Programme 2007-2013.

Borodina, O. and Shevchyshyn, M. (2008) 'Renewable energy - prospects for agriculture Ukraine', Propozitsiya, No. 10, pp.90-94.

Charles, C., Gerasimchuk, I., Bridle, R., Moerenhout, T., Asmelash, E. and Laan, T. (2013) Biofuels - At What Cost? A Review of Costs and Benefits of EU Biofuel Policies, April, 125pp, The International Institute for Sustainable Development.

Crop Monitoring in Europe (2012) MARS Bulletin, Vol. 20, No. 5, 39pp.

Drabik, D. (2012) The theory of biofuel policy and food grain prices, edited by C.H. Dyson, School of Applied Economics and Management Working paper \# 2011-20, Cornell University, Ithaca, USA [online] http://dyson.cornell.edu/research/researchpdf/wp/2011/ Cornell-Dyson-wp1120.pdf (accessed 24 March 2012).

European Biodiesel Board (EBB) (2011) European Biodiesel Board: Statistics [online] http://www.ebb-eu.org/stats.php (accessed 9 May 2011).

European Commission (2016) Excise Duty Tables. Part II - Energy Products and Electricity, January, B-1049, Office: SPA3 5/69A, 80pp, Brussels, Belgium.

Farm Security and Rural Investment Act of 2002 (2002) May, 540pp, Washington.

Fay, M. and Barros, S. (2013) Biofuels Annual. Annual Report 2013, GAIN Report No. BR13005, 9 December 2013, 28pp, Brazil.

Federal Government of Germany (2006) 20th Federal Subsidy Report: Bericht der Bundesregierung über die Entwicklung der Finanzhilfen des Bundes und der Steuervergünstigungen für die Jahre 2003 bis 2006, Government of Germany, Berlin.

Federal Government of Germany (2007) 21st Federal Subsidy Report: Bericht der Bundesregierung über die Entwicklung der Finanzhilfen des Bundes und der Steuervergünstigungen für die Jahre 2005 bis 2008, Government of Germany, Berlin.

Federal Government of Germany (2011) Zehnte Verordnung zur Durchführung des BundesImmissionsschutzgesetzes (Verordnung über die Beschaffenheit und die Auszeichnung der Qualitäten von Kraft- und Brennstoffen - 10. BImSchV), Federal Government of Germany [online] http://www.bundesrat.de/SharedDocs/Drucksachen/2010/0601-700/67510,templateId=raw,property=publicationFile.pdf/675-10.pdf (accessed 5 June 2011).

Federation on Tax Administrators (2015) State Motor Fuel Tax Rates, January.

Havrysh, V. (2007) Effective Use of Energy Resources in the Agricultural Sector: The Theory, Methodology, Practice: Monograph, 283pp, MDAU, Mykolayv.

Josling, T., Blandford, D. and Earley, J. (2010) Biofuel and Biomass Subsidies in the US, EU and Brazil: Towards a Transparent System of Notification, September, 48pp, International Food and Agricultural Trade Policy Council.

Kirilenko, I., Melnik, Y., Prysyazhnyuk, M., Andrievskiy, V. et al. (2009) Actual Problems of Agrarian Reform in Ukraine in Terms of the Systemic Crisis of the World Economy, 135pp, Coordinating Council for Agricultural Policy at Cabinet of Ministers of Ukraine, Kyiv.

Klavdienko, V. and Tarasov, A. (2006) 'Alternative energy in the EU: economic incentives for the development', Energy, Vol. 9, No. 9, pp.42-46.

Leduc, S., Natarajan, K., Dotzauerc, E., McCallum, I. and Obersteiner, M. (2009) 'Optimizing biodiesel production in India', Applied Energy, November, Vol. 86, No. Supplement 1, pp.S125-S131.

Li, J. (2014) 'The future of biogas in China', Biogas World, 1 April, 18pp, Berlin, Germany.

MacDonald, T. (2004) Ethanol Fuel Incentives Applied in the US, January, Staff Report, P600-04001, 32pp.

Mallory, M.L., Irwin, S.H. and Hayes, D.J. (2012) 'How market efficiency and the theory of storage link corn and ethanol markets', Energy Economics, Vol. 34, No. 6, pp.2157-2166. 
Manifesto (2013) Leaders of Sustainable Biofuels [online] http://www.sustainablebiofuelsleaders. com/img/Manifesto.pdf (accessed 12 January 2016).

MECAS (2012) The Outlook of Sugar and Ethanol Production in Brazil, March, No. 12, 51pp, International Sugar Organization, London.

Moreira, J.R. (2007) Biofuel in Brazil: Past and Present, 4-5 October, UC Berkeley, Berkeley, California.

Nassar, A.M. and Ures, D. (2009) Brazil: Shadow WTO Agricultural Domestic Support Notification, IFPRI Discussion paper, No. 865.

NGVJournal, Worldwide NGV Statistics [online] http://www.ngvjournal.com/worldwide-ngvstatistics-2 (accessed 21 January 2016).

Rauch, A. (2012) Biofuels - At What Cost? Mandating Ethanol and Biodiesel Consumption in Germany, edited by A. Rauch and M. Thöne, January, 59pp, FiFo Institute.

Shiyan, C., Lili, Z., Timilsina, G.R. and Xiliang, Z. (2012) Development of Biofuels in China: Technologies, Economics and Policies, The World Bank, October, 34pp, Development Research Group: Environment and Energy Team.

The Statistics Portal (2014) Gasoline Prices in Selected Countries Worldwide as of November 2014 (in US Dollars per Gallon) [online] http://www.statista.com/statistics/221368/gas-pricesaround-the-world/ (accessed 21 January 2016).

Toffler, A. (1999) The Third Wave, 386pp, AST, Moscow.

Tokgoz, S., Zhang, W., Msangi, S. and Bhandary, P. (2012) 'Biofuels and the future of food: competition and complementarities', Agriculture, Vol. 2, No. 4, pp.414-435.

US Congress (2014) The Renewable Fuel Standard: Issues for 2014 and Beyond, June, 38 pp, Congressional Budget Office.

US Department of Energy: Energy Efficiency and Renewable Energy (2014) Clean Cities Alternative Fuel Price Report, October, 17pp.

Vacha, L., Janda, K., Kristoufek, L. and Zilberman, D. (2012) 'Time-frequency dynamics of biofuels-fuels-food system' [online] http://arxiv.org/pdf/1209.0900.pdf (accessed 14 December 2015).

Verband der Deutschen Biokraftstoffindustrie e.V. (VDB) (2011a) Factssheet zu Bioethanol, Stand: März 2011, Verband der Automobilindustrie [online] http://www.biokraftstoffverband.de/downloads/1894/VDB_Facts_Bioethanol.pdf (accessed 10 June 2011).

Verband der Deutschen Biokraftstoffindustrie e.V. (VDB) (2011b) Vorteil Biodiesel, Verband der Deutschen Biokraftstoffindustrie [online] http://www.biokraftstoffverband.de (accessed 18 May 2011).

Verband der Deutschen Biokraftstoffindustrie e.V. (VDB) (2011c) Vorteil Bioethanol, Verband der Deutschen Biokraftstoffindustrie, http://www.biokraftstoffverband.de (accessed 18 May 2011).

Wisner, R. (2012) 'Ethanol exports: a way to scale the blend wall?', AgMRC Renewable Energy and Climate Change Newsletter, February.

Wright, B. (2011) Biofuels and Food Security: A Need to Consider Safety Valves?, February, International Food and Agricultural Trade Policy Council.

Wright, T. and Rahmanulloh, A. (2015) Indonesia Biofuel Annual Report 2015, Gain Report No. ID1525, 12pp, USDA Foreign Agriculture Service.

$\mathrm{Xu}, \mathrm{Y}-\mathrm{J} ., \mathrm{Li}, \mathrm{G}-\mathrm{X}$. and Sun, Z-Y. (2016) 'Development of biodiesel industry in China: upon the terms of production and consumption', Renewable and Sustainable Energy Reviews, February, Vol. 54, No. 5156, pp.318-330.

Yerokhin, A. (2009) 'The condition and the possibility of biofuel production in Ukraine', Seminar on the Study of Practical Examples of Overcoming Obstacles to Investing in Projects in Efficiency and Renewable Energy Development Through Policy Reforms, 10-11 November, Kyiv. 
Zhou, A. and Thomson, E. (2009) 'The development of biofuels in Asia', Applied Energy, November, Vol. 86, No. Supplement 1, pp.S11-S20.

\section{Websites}

http://www.biofuelsdigest.com/bdigest/2013/12/31/biofuels-mandates-around-the-world-2014. 